\title{
The Willingness to Devote Time to Volunteers Projects in Relation to Volunteers Practice
}

\author{
Lucie Zárubová, ${ }^{1 *}$, and Lenka Švecová ${ }^{2}$ \\ ${ }^{1}$ University of West Bohemia, Faculty of Economics, Univerzitní 22, Pilsen, 306 14, the Czech \\ Republic \\ ${ }^{2}$ University of Chemistry and Technology Prague, Techncká 5, Praha 6, 160 00, the Czech Republic
}

\begin{abstract}
.
Research background: The article deals with the volunteering. The relationship between school and volunteer orientation is compared among respondents preparing for the future labour market, i.e. high school and university students of various specializations who study in the Czech Republic. Students can be motivated by gaining experience in team cooperation in solving a common goal like one type of the motivator. Are volunteers and potential volunteers willing to devote their time to projects in the same way, whether they have experience with volunteering or not?

Purpose of the article: The purpose is to find the connection between the age of the respondents, their experiences with volunteering and the time they are willing to devote to the volunteering.

Methods: The method is quantitative study of answers of students from high school and university students. The quantitative study uses Chi square test. The result of quantitative elaboration of the questionnaire survey is the answer to whether there is a connection between the age of the respondents, their experience with volunteering and the time which they are willing to devote to the volunteering.

Findings \& Value added: The result finds the differences and connections between age of volunteers, their experiences with volunteering and with willingness to be the volunteer for longer or shorter time. The result of the survey brings benefits to managers to recruit volunteers and it cannot be denied that the willingness of volunteers to devote their time to volunteering will change as they gain the experience.
\end{abstract}

Keywords: volunteer; motivation; student; time of projects

JEL Classification: $M 50 ;$ M51; M54

\footnotetext{
*Corresponding author: zarubovl@kpm.zcu.cz
} 


\section{Introduction}

Projects in contributory organizations or non-profit organizations (NGOs) are often subsidized in our territory from European funds [1]. According to Golini, Kalchschmidt, \& Landoni [2], their performance in measuring efficiency is at a low level. In practice, this means that efficiency is not measured at all and project documentation activities are managed at a level that covers the requirements of the grant procedure often. Project management and focus on the goal also helps to manage the motivation of volunteers. A volunteer is a person who performs an activity, a service, an activity that does not target for his own benefit, but he/she enriches someone else [22]; [3]; [4]. Golini, Kalchschmidt, $\&$ Landoni [2] focus on the analysis of project management from a management perspective. This article focuses on the impact of volunteers' previous experience with volunteering, specifically by managing volunteering on projects in terms from the point of view of volunteer age and willingness to participate in volunteering in the Czech Republic repeatedly. The results of Zárubová, \& Švecová [5]; [6]; [7] point to the motivation of volunteers in terms of various factors. It was confirmed that it cannot be ruled out that the motivation of volunteers and other people is different [5], further that the motivation of volunteers is connected with study [6] and that the targeting of volunteers and other people is different [7]. According to these findings, it is expected that the result of the article will be information that it cannot be denied that the organization of volunteering helps not only project management [2], but also in formal volunteering (organizationally based volunteering) it helps to motivate the repetition of volunteering work and more realistic expectations of volunteers about possibilities of time and terms.

Work experience and experience are valued in the labor market, some volunteers reach for volunteer work to gain experience. Career volunteering can be a response to the complex social, political or economic situation of a family or state [8]. Volunteering serves as an opportunity to develop your own education and other skills [9]. Discuss the topic of interaction between professional development of trainees and volunteer status, including vulnerability, participation in professional activities and transition to paid employment [7]. Volunteer support and leniency are higher than for paid work. This support plays an important role in maintaining and stimulating the volunteer's motivation. Education through volunteer work can be realized through the repetition of knowledge that is reflected in practice and transforms it. Self-development is conditioned by a degree of self-reflection, which ensures that the individual is aware that he can control his personal development [10]; [11].

\section{The willingness to work and motivation of volunteer}

Volunteering is a widespread theme that transcends the boundaries of nations, states and religions. It has been present in society for a long time and we can say that its importance is growing worldwide. Volunteers help in natural disasters, wars and the like [12].

The activities of volunteers, as well as contributory organizations and NGOs focused on working with volunteers, are associated with identification with the social values of society and the sustainable provision of goods and services locally and globally as well [13]. Motives are associated with social, cultural, environmental or work missions [14]. Volunteer project organizations must provide an evaluation of their purpose and goals and process the evaluation process of their key customers, employees and resources to achieve the desired result [13]

Volunteers are educated and educated in their position [15]; [16]; [17]; [23]. Volunteer education is divided into formal (e.g., training, courses, coaching) and non-formal (e.g., 
learning through sharing or cultural immersion) [16]. Formal volunteering is organized. Examples of volunteer work include election activities, community events, religious activities, the environment, working with animals, and assistance with people with special needs, adult education and fundraising [22]; [5].

Volunteers join for various complex reasons, especially altruism and different personal meanings [18]. When selecting projects, they evaluate workplace relationships, health benefits, new knowledge and competencies, and expect professionalism and good organization [19]; [6]. Motivated individuals that manager evaluates them and have pre-set achievable goals are willing to work longer than individuals who are not driven. It is possible to hire motivated volunteer and the volunteer loose the motivation without managing and good cooperation [20]; [21].

\section{Research}

154 respondents at the age of high school and university completed the questionnaire. Respondents are people living in the Czech Republic preparing for their future profession. The questionnaire consisted of several questions. Some of them were demographic issues and others concerned the experience of volunteering and the willingness to volunteer repeatedly. Gender responses are balanced with a deviation of $10 \%$ for one school group. Respondents are located mainly in the territory of Prague from $70 \%$. The remaining $30 \%$ of respondents are located throughout the Czech Republic. The exact location in the Czech Republic does not indicate any direction of research, and therefore the geographical division of the Czech Republic is not examined later. The questions were first tested in a control group and later, after fine-tuning, the questionnaire was distributed online. Values that were extreme, false, were excluded from the subject of research. The volunteers' response to the willingness to devote a numerical amount of time to volunteering was an open response.

The hypothesis was formulated: "People who have been and have not been volunteers have a relationship between experience and time who are willing to volunteer."

Respondents are persons over 18 years of age and under 30 years of age. The distribution of volunteers is shown in Figure 1. Figure 1 is the subject of author's research. The questionnaire also addressed foreign volunteering, which is possible only after reaching the age of majority in the Czech Republic.

This corresponds to the distribution of respondents, where the majority are university students. The distribution of the group of respondents according to their educational focus is as follows: General - 15 respondents; Social and Psychology - 33 respondents; Humanitarian - 43 respondents; Technical - 30 respondents; Economy - 19 respondents; Creative -14 respondents. 


\section{Type of school}

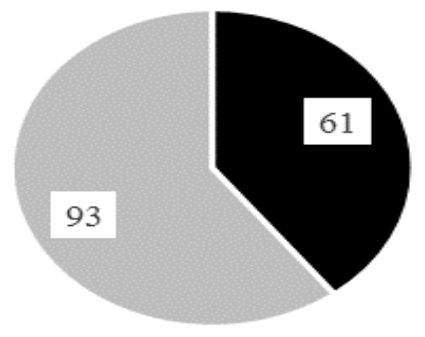

- High school = University

Fig. 1. The distribution of respondents.

Table 1 graphically shows the distribution of the answer in the questionnaire. Table 1 is the subject of author's research. The division is according to the degree of study and later according to the experience of volunteering and the desire to volunteer in the future. It can be deduced from the table that the respondents, regardless of the level of study, if they did not volunteer, usually do not want to volunteer even in the planned future.

Table 1. The distribution of respondent's answer.

\begin{tabular}{|c|c|c|c|c|c|c|c|}
\hline \multicolumn{9}{|c|}{ High school } & \multicolumn{5}{c|}{ University } \\
\hline \multicolumn{2}{|c|}{$\begin{array}{c}\text { Was Volunteer and } \\
\text { wants to be again }\end{array}$} & $\begin{array}{c}\text { Wasn't volunteer and } \\
\text { wants to be }\end{array}$ & \multicolumn{2}{|c|}{$\begin{array}{c}\text { Was Volunteer and } \\
\text { wants to be again }\end{array}$} & $\begin{array}{c}\text { Wasn't volunteer and } \\
\text { wants to be }\end{array}$ \\
\hline Yes & No & Yes & No & Yes & No & Yes & No \\
\hline 28 & 7 & 10 & 16 & 40 & 14 & 18 & 21 \\
\hline
\end{tabular}

Table 2 graphically shows the distribution of the answer in the questionnaire about time of willingness to be a volunteer. Table 2 is the subject of author's research. Not surprisingly, estimates of willingness to give time for future volunteering are highest in all groups where respondents respond that they would like to volunteer. Most respondents were willing to devote their time to a few hours a week. 


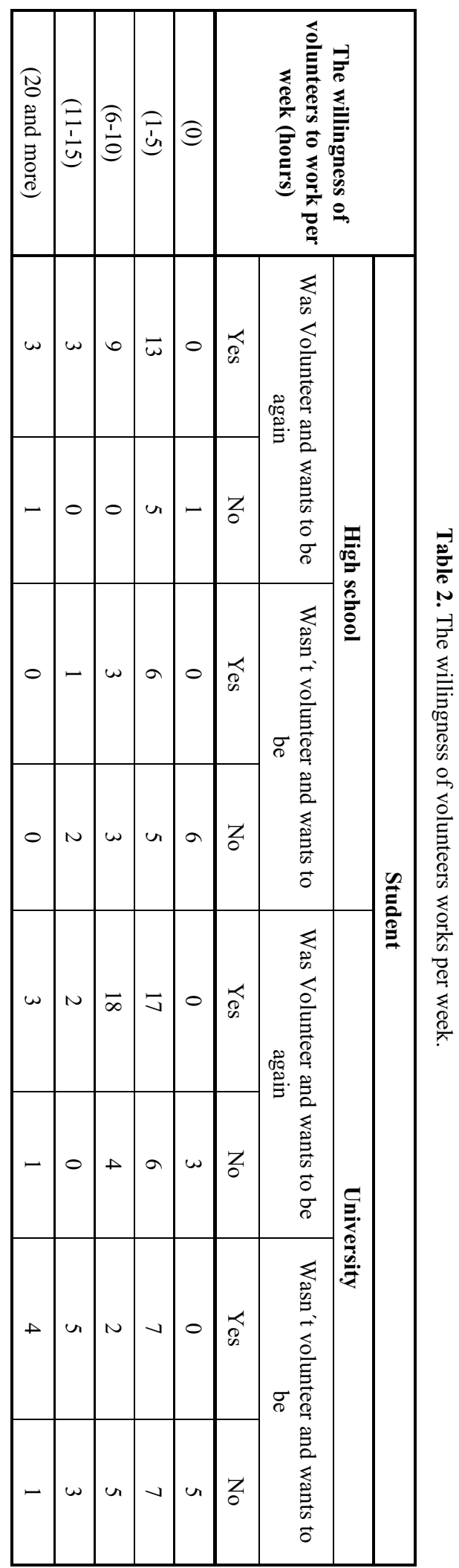




\section{Results of research}

Chi-squared $\left(\chi^{2}\right)$ test was used for testing the hypothesis: "People who have been and have not been volunteers have a relationship between experience and time who are willing to volunteer."

The input data are shown in figures up for above four mentioned categories of respondents. The test is performed at a significance level of 5\%. The data was optimized for the possibility of using the chi square test. The value of $\chi^{2}$ is 32,3321 and with 28 degrees of freedom, the critical $\chi^{2}$ value is 41,337 . It means that the dependence between quantities was confirm. Therefore, the hypothesis, that people who have been and have not been volunteers have a relationship between experience and time who are willing to volunteer can not be rejected.

\section{Conclusion}

People who have been and have not been volunteers have a relationship between experience and time who are willing to volunteer can not be rejected. Respondents who want to volunteer are willing to devote more time to volunteering. The dependence of the data has been confirmed. Volunteers are most willing to dedicate their time per week to approximately 1-5 hours. In the second case, volunteers were willing to devote 6-10 hours a week to volunteering. Lower and higher intervals are in the minority of answers. There are other ways to look at volunteer motivation and management. It would be interesting to find them, which could lead to other interesting results. The willingness to devote time to volunteering is valued not only as gaining experience, but also as a willingness to work beyond measure than financial expectations. That is why volunteering is now valued and projects are opened in the private sphere in the field of social responsibility of the companies [8]. Volunteers like to get involved in mass activities if they typically apply for collective volunteering in the services of [10]; [11]. Effectiveness and goal management supports his willingness to engage in volunteering to return to the volunteer process. It has not been confirmed that with experience, the trend of willingness to engage more in terms of time increases, but this has not been refuted. At this point, there is a stimulus for a longitudinal study that could lead to information that could not be explored in this research. In the discussion on this topic, it would be appropriate to expand the sample of respondents and its analysis depending on other factors, such as the form of volunteering, the length of previous paid work experience, etc. Personality types, communication methods can also influence volunteer management. Research in this regard can bring interesting conclusions on this topic. In this research, the theoretical thinking of the respondents was monitored in a certain period.

\section{References}

1. Svecova, L., Fanta, P., Zarubova, L. (2020). Implementation of project management approaches in projects financed by EU structural funds (case study of the Czech Republic). The 14th International Days of Statistics and Economics. 
2. Golini, R., Kalchschmidt, M., Landoni, P. (2015). Adoption of project management practices: The impact on international development projects of non-governmental organizations. International Journal of Project Management, 33(3), 650-663.

3. Pompurova, K., Sokolova, J., Cole, D., Marcekova, R., Koziak, R. (2020). Are visitors interested in volunteer tourism? Evidence from Slovakia. Entrepreneurship and Sustainability Issues, 7(4), 3339-3353.

4. Bíl, M., Heigl, F., Janoška, Z., Vercayie, D., Perkins, S. E. (2020). Benefits and challenges of collaborating with volunteers: Examples from National Wildlife Roadkill Reporting Systems in Europe. Journal for Nature Conservation, 54, 125798.

5. Zarubova, L., Svecova, L. (2019a). Does a difference in the motivation of volunteers and other people exist? The 13th international days of statistics and economics, 17071716.

6. Zarubova, L., Svecova, L. (2019b). Is volunteering a way how students get the practice? IFRS: Global Rules \& Local Use 2019: Beyond the Numbers, 310-321.

7. Zarubova, L., Svecova, L. (2020). Does a difference between volunteers and other people's focus an self-development targeting exist? Proceedings of the "New Silk Road: Business Cooperation and Prospective of Economic Development" (NSRBCPED 2019) (pp. 552-557).

8. Duguid, F., K. Mündel, D. Schugurensky. (2013). Volunteer work, informal learning and social action. Rotterdam: Sense Publishers.

9. Thompson, R., Russell, L. (2017). Trainee teachers in unpaid teaching posts: volunteering, risk and vulnerability. Journal of Vocational Education \& Training, 69(4), 637-654.

10. Carini, RM, Kuh, GD, Klein, SP. (2006). Student engagement andstudent learning: Testing the linkages. Res High Educ.

11. Cui, G., Yao, M., Zhang, X., Guo, Y., Li, H., Yao, X. (2016). The effects of initial participation motivations on learning engagement in transition training for future general practitioners in rural China: Perceived deterrents as mediator. Medical Education Online, 2016.

12. Dolezel, J. (2016). Catholic Charitable Social Work in the Former Czechoslovakia: With a Focus on the Czech Lands. European Journal of Mental Health, 11(01-02), 7996.

13. Sebestova, J., Haltofova, P. (2014). Volunteer work in the context of social services in the Czech Republic. Procedia Economics and Finance, 12, 670-678.

14. Borzaga, C., Defourny, J. (2001). The emergence of social enterprise. London: Routledge.

15. Falk, J., R. Ballantyne, J. Packer, P. Beckendoriff (2012). Travel and learning: A neglected research area. Annals of Tourism Research, 39(2), 908-927.

16. Ritchie, B., N. Carr, C. Cooper. (2003). Managing educational tourism. Clevedon: Channel View.

17. Stone, N., J. Petrick. (2013). The educational benefits of travel experiences: A Literature Review. Journal of Travel Research, 52(6) 731-744.

18. Nichols, G., Hogg, E., Knight, C., Storr, R. (2019). Selling volunteering or developing volunteers? Approaches to promoting sports volunteering. Voluntary Sector Review, 10(1), 3-18. 
19. Kost, R. G., Lee, L. M., Yessis, J., Coller, B. S., Henderson, D. K. (2011). Assessing research participants' perceptions of their clinical research experiences. Clinical and Translational Science, 4(6), 403-413.

20. Vetrakova, M., Kubala, J., Cole, D. A., Pompurova, K. (2020). Causes of employee fluctuation and the need for stabilization in Slovak hotels. Entrepreneurship and Sustainability Issues, 8(1), 332-346.

21. Lourens, G. M., Daniels-Felix, D. K. (2017). Hospital volunteerism as human resource solution: Motivation for both volunteers and the public health sector. SA Journal of Human Resource Management, 1(2).

22. Elrod, L. M. M. (2019). Volunteering. Salem Press Encyclopedia.

23. Van't Klooster, E., J. van Wijk, F. Go, J. van Rekom. (2008). Educational Travel. 